\title{
FAST-TRACK SURGERY AND EARLY REHABILITATION FOR TOTAL HIP REPLACEMENT IN HOSPITAL OF TRAUMATOLOGY AND ORTHOPAEDICS
}

\author{
Miḳelis Birznieks ${ }^{1, \#}$, Iveta Golubovska ${ }^{1,2}$, Lauris Repša ${ }^{3}$, Inta Čerṇavska ${ }^{2}$, Jānis Ābols ${ }^{2}$, \\ Aivars Muste ${ }^{2}$, Igors $\mathrm{Lu}^{2}$, and Aleksejs Miščuks ${ }^{1,2}$ \\ ${ }^{1}$ Faculty of Medicine, University of Latvia, 3 Jelgavas Str., Rīga, LV-1004, LATVIA \\ 2 Department of Anaesthesiology and Intensive Care, Hospital of Traumatology and Orthopaedics, 22 Duntes Str., Rīga, \\ LV-1005, LATVIA \\ ${ }^{3}$ Center of Spine and Joint Surgery, Hospital of Traumatology and Orthopaedics, 22 Duntes Str., Rīga, LV-1005, LATVIA \\ \# Corresponding author, mikelis.birznieks@gmail.com
}

Communicated by Ingrīda Rumba-Rozenfelde

\begin{abstract}
Due to an ageing population, the necessity for hip replacement has grown, and therefore, new options are being sought, such as the Fast-track principle, to improve patient condition, reduce their hospital stay and enhance the hospital's ability to treat more patients. The aim of this study was to investigate the effects of same-day patient mobilisation on pain, side effects, complications, duration of hospital stay, and recovery after primary hip replacement, using intermediateacting local anaesthetics in spinal anaesthesia (SA). A prospective, randomised study was conducted at the Hospital of Traumatology and Orthopaedics. Forty-six patients undergoing total hip replacement were selected and divided into two groups. Spinal anaesthesia was performed in study group $(P)$ with $70 \mathrm{mg}$ plain prilocaine. The control group $(B)$ received $18 \mathrm{mg}$ heavy bupivacaine in SA. On the first postoperative day, pain during movement was $2.00(P)$ and $3.33(B)$ on the Numeric Pain Rating Scale, the duration of hospital stay in the study group was shorter by $\sim 1$ day, and patient self-care was better in the study group. When the Fast-track principle is used with intermediate-acting $S A$ and early rehabilitation, it is possible to reduce post-operative pain during movement, reduce the length of stay and improve patient self-care abilities.
\end{abstract}

Key words: total hip replacement, prilocaine, spinal anaesthesia, early mobilisation, postoperative pain.

\section{INTRODUCTION}

Total hip replacement (THR) is replacement of damaged parts of the hip joint with a prosthesis. More than 1 million THRs are conducted yearly with excellent results. Approximately $95 \%$ of the implants last for 10 years and more than $80 \%$ of the implants last for 25 years. THR has now become the standard for end stages of degenerative hip diseases. Despite the good results, new and better solutions from surgical, anaesthetic, nursing and organisational points of view are constantly being sought to reduce the number of complaints, costs and length of stay in the hospital, which is approximately eight days in the Hospital of Traumatology and Orthopaedics (information from hospital archives). New solutions are necessary both to improve the quality of life for patients and to maximize the number of possible operations performed by a hospital, since the amount of necessary THR's is expected to increase exponentially. In USA alone, it is expected that necessary THR's will increase by $174 \%$ per annum by 2030, but in the world this figure could be twice as high (Zagra, 2017).

The idea of a multimodal treatment approach was first formulated and published by Prof. Henrik Kehlet in 1997. In his opinion, despite progress in the surgical and anaesthetic sectors, none of the new findings alone can seriously reduce morbidity and mortality. However, using a multidisciplinary approach, adverse reactions could be avoided and patient recovery could be improved, which would further reduce the overall cost to the patient and the hospital.

In his opinion, several factors should be recognised, treated, or avoided. He described co-morbidity, malnutrition and al- 
cohol as preoperative risk factors. He referred to surgical stress, heat loss and blood transfusions at the intraoperative level. In addition, postoperative risk factors included postoperative pain, immunosuppression, nausea and vomiting, hypoxaemia, sleep disturbances, increased catabolism, immobilisation, drainage, nasogastric tubes, and various obsolete traditions in hospital departments (Kehlet, 1997).

Initially, these principles were developed for abdominal surgery, but they were further adapted to various other types of surgery, such as gynaecological, cardiothoracic and orthopaedic surgery, with them being known as Enhanced Recovery protocols or Fast-track protocols. Over time, different aspects of these protocols have been updated with the most relevant advances in medicine.

One of the main sections of Fast-track protocols is early mobilisation of the patient. In recent years, recommendations have been made to decrease time between surgery and mobilisation after hip replacement (Bandholm and Kehlet, 2012). Usually that means mobilisation on the first or second postoperative day, but there are few studies that have implemented same-day patient mobilisation for inpatient hip replacement (Okamoto et al., 2015; Pelt et al., 2016). Even though these studies achieved great results, we were unable to find any studies that did this by using prilocaine in spinal anaesthesia.

We hypothesised that by combining this spinal anaesthetic with multimodal analgesia and early rehabilitation, it is possible to accelerate the recovery of patients, which would expedite patient's discharge.

Prilocaine is a short to intermediate-acting amino amide with lower central nervous system toxicity and a rapid degradation time. Recently, this drug has been used in spinal anaesthesia for short and medium-length operations in place of lidocaine due to less transient neurological symptoms, with particular emphasis on outpatient surgery (Kaban et al., 2014; Manassero and Fanelli, 2017).

The aim of this study is to prove our hypothesis that patient recovery can be improved and accelerated using this method.

\section{MATERIALS AND METHODS}

A prospective, randomised study was conducted at the Centre of Spine and Joint surgery, Hospital of Traumatology and Orthopaedics, from September 2017 to March 2018. The Ethics Commission of the Hospital of Traumatology and Orthopaedics approved the research.

A total of 64 patients were selected, eight of whom refused to participate in the study. Eight patients did not undergo an operation during the study period, and 48 patients agreed to participate in the study. For two patients, the operation was cancelled, while 46 patients had surgery. Of these, 22 patients were assigned to the study group $(\mathrm{P})$ and 24 patients to the control group (B).
Patients were selected for the study on a working day and Sunday afternoons when they planned to arrive in the hospital for the upcoming surgery next day. The inclusion criteria to offer the patient to participate in the study were: age between 18 and 75 years; BMI $<35 \mathrm{~kg} / \mathrm{m}^{2}$; planned unilateral, primary, total hip replacement; ASA < III Class; the patient was motivated to follow the study conditions; and agreed to participate.

The exclusion criteria were: allergy or intolerance to the medication included in the study; inflammatory arthritis; history of myocardial infarction, pulmonary embolism, deep vein thrombosis, type 1 diabetes mellitus, atrial fibrillation or pacemaker; prolonged use of preoperative anticoagulants; steroid therapy during the previous year; malignancy, neurological or balance problems; and patient is already included in a different study.

On the day of admission, the patients signed an informed consent form. Data on the patient's history, age, ASA score, and body mass index were obtained. Subsequently, patients were randomised into study and control groups using the "Research randomizer" free access programme. In the study group, the operation was performed on round one or two (until 12:00) on Monday, Tuesday or Wednesday with spinal anaesthesia (SA) using $70 \mathrm{mg}$ plain prilocaine and patients were mobilised on the same day. In the control group, the operation was performed on any workday and round with SA, using $18 \mathrm{mg}$ of heavy bupivacaine, and patients were mobilised the next day after surgery.

All patients received: Sol. Cefazolinum 2 g i/v 30 min before skin incision, infusion with $1200 \mathrm{ml}$ of crystalloids and $500 \mathrm{ml}$ of colloids; infusion of Tranexamicum acid $1 \mathrm{~g} 15$ min before skin incision and 6 hours after surgery, Dexamethasonum $8 \mathrm{mg}$ i/v before surgery, local infiltration anaesthesia (LIA) during surgery with ropivacaine $0.75 \%$ (30 ml for weight $<75 \mathrm{~kg}, 40 \mathrm{ml}$ for weight 75-100 kg, 50 $\mathrm{ml}$ for weight $>10 \mathrm{~kg}$ ) diluted with $0.9 \% \mathrm{NaCl}$ for total volume of $100 \mathrm{ml}$, bemiparinum $3500 \mathrm{DV}$ s/c for three days, after that rivaroxabanum $10 \mathrm{mg}$ p/o once per day for one month.

Both groups received multimodal analgaesia: acetaminophen $1 \mathrm{~g} \mathrm{i} / \mathrm{v}$ after surgery and every 8 hours until 8:00 of first postoperative day (POD1), then $500 \mathrm{mg}$ P/O every 6 hours for five days; etoricoxibum $90 \mathrm{mg}$ p/o in premedication and once per day for five days; morphine $30 \mathrm{mg}$ p/o, if the pain was greater than Numeric Pain Rating Scale $(\mathrm{NPRS})=5$.

On the first post-operative day, patients were interviewed about pain while stationary and during movement using the NPRS and were interviewed for adverse reactions. The NPRS is a segmented numeric version of the visual analogue scale (VAS) in which a respondent selects a whole number ( $0-10$ integers) that best reflects the intensity of his/her pain. The 11-point numeric scale ranges from '0' representing one pain extreme (e.g. "no pain") to '10' representing the other pain extreme (e.g. "pain as bad as you can 
PATIENT CHARACTERISTICS

\begin{tabular}{|c|c|c|c|c|c|}
\hline \multirow[t]{2}{*}{ Group } & \multirow[t]{2}{*}{ All patients } & \multirow[t]{2}{*}{ Study group } & \multirow[t]{2}{*}{ Control group } & \multicolumn{2}{|c|}{ Statistical analysis } \\
\hline & & & & $\mathrm{P}_{\gamma} / \mathrm{P}_{\mathrm{MV}}$ & $\mathrm{V} \eta$ \\
\hline Mean age, \pm SD & $56.70 \pm 12.79$ & $57.82 \pm 11.41$ & $55.67 \pm 14.09$ & $\mathrm{P}_{\mathrm{MV}}=0.64$ & $\eta=0.08$ \\
\hline Male patients, $\%$ & 41.30 & 45.45 & 37.50 & $\mathrm{P}_{\chi}=0.58$ & $\mathrm{~V}=0.08$ \\
\hline Female patients, $\%$ & 58.70 & 54.55 & 62.50 & & \\
\hline ASA Class I , \% & 2.17 & 0.00 & 4.17 & $\mathrm{P}_{\chi}=0.28$ & $\mathrm{~V}=0.28$ \\
\hline ASA Class II , \% & 80.43 & 90.91 & 70.83 & & \\
\hline ASA Class II/III, \% & 15.22 & 9.09 & 20.83 & & \\
\hline $\mathrm{BMI} \mathrm{kg} / \mathrm{m}^{2}, \pm \mathrm{SD}$ & $28.23 \pm 4.38$ & $28.60 \pm 3.87$ & $27.89 \pm 4.86$ & $\mathrm{P}_{\mathrm{MV}}=0.52$ & $\eta=0.08$ \\
\hline
\end{tabular}

imagine" or "worst pain imaginable") (Anonymous, 2019).

Table 2

Patient histories provided data on the date of commencement of rehabilitation, the need for opioids for pain relief, blood loss during and after surgery, and the need for and volume of transfusions. After the patient's departure, data was collected on the duration of the patient's stay, and one week after discharge, a telephone conversation was conducted, during which the pain levels in the resting state and movement, the ability to climb stairs, and the ability for self-care were determined. A patient's ability to put on socks without any assistance was chosen as a self-care indicator.

Data from patients histories, post-operative and follow-up interviews were entered into Microsoft Excel 2016 and data were analysed using the IBM SPSS Statistics 25.0 statistical software. For the values for which the mean and standard deviation were determined, a 95\% confidence coefficient (CI 95\%) was also determined, indicating a range of values with a 95\% confidence level of a similar group mean. For ordinal values, median and interquartile range (IQR) were determined. The difference between groups was determined using the chi-square (or $\chi^{2}$ ) criterion method or Fisher's direct test. A significant difference between groups was considered if the statistical probability $\left(\mathrm{P}_{\chi}\right)$ was less than 0.05 . In order to determine relationships between nominal data, the Cramer's V correlation coefficient was used. The Mann-Whitney test was used to compare nominal data. When analysing the relationship between nominal data and numerical data (a specific number that is measurable), the Eta correlation coefficient $(\eta)$ was selected.

\section{RESULTS}

A total of 46 patients were analysed, of which 22 or $47.83 \%$ were included in the prilocaine group, while the remaining 24 or $52.17 \%$ were in bupivacaine or control group. The average age of patients was $56.70, \mathrm{SD}=12.79$ years, ranging from 18 to 72 years (Table 1 ). In the study group, the average patient age was $57.82, \mathrm{SD}=11.41$ years, and in the control group, the average age of patients was $55.67, \mathrm{SD}=$ 14.09 years. The difference between age in the groups was not statistically significant $\left(\mathrm{P}_{\mathrm{MV}}=0.64\right)$. In general, 19 patients, or $41.30 \%$, were men, while 27 or $58.70 \%$ were

MEAN PAIN LEVEL ON POD1

\begin{tabular}{l|c|c|c|c}
\hline \multirow{1}{*}{ Group } & \multicolumn{4}{c}{ Pain level } \\
\cline { 2 - 5 } & median & interquartile range & $\min$ & $\max$ \\
\hline \multirow{4}{*}{ While Stationary } \\
All patients & 0 & 1.00 & 0 & 4.00 \\
Study group & 0 & 0 & 0 & 3.00 \\
Control group & 0 & 2.00 & 0 & 4.00 \\
& & During Movement & & \\
All patients & 3.00 & 3.00 & 0 & 8.00 \\
Study group & 2.00 & 3.00 & 0 & 7.00 \\
Control group & 3.00 & 3.00 & 0 & 8.00
\end{tabular}

women. By gender distribution, the two groups did not differ statistically significantly $\left(P_{\dot{\div}}=0.58\right)$. Analysing the patient group by ASA scale, the majority of all patients, or $80.34 \%$, were Class II patients or patients with mild systemic diseases. The difference between groups was not statistically significant $\left(\mathrm{P}_{\chi}=0.28\right)$.

The mean score for the level of pain in the first postoperative day during movement was 2.70 (median 3.00, IQR 3.00) (Table 2) corresponding to the NPRS3 group. In the study group, the mean pain level during the movement was 2.00 (median 2.00, IQR 3.00), corresponding to the NPRS2 group, and 3.33 (median 3.00, IQR 3.00) in the control group corresponding to the NPRS3 group.

In the study group (Fig. 1), only 59.09\% of patients received rehabilitation at the appropriate time (on the day of the surgery), while $87.50 \%$ of the control group patients received it at the appropriate time (first postoperative day). This difference between study and control groups was statistically significant $\left(\mathrm{P}_{\chi}=0.0284\right)$. The relationship between the anaesthetic and the corresponding rehabilitation was high $(\mathrm{V}=0.32)$.

The relationship between the duration of hospitalisation and anaesthetic used is shown in Figure 2. Patients treated with bupivacaine spent on average 1 day longer in the hospital than patients treated with prilocaine. This difference was statistically significant $\left(\mathrm{P}_{\mathrm{MV}}=0.0495\right)$. However, it should be noted that the obtained significance level was borderline, 

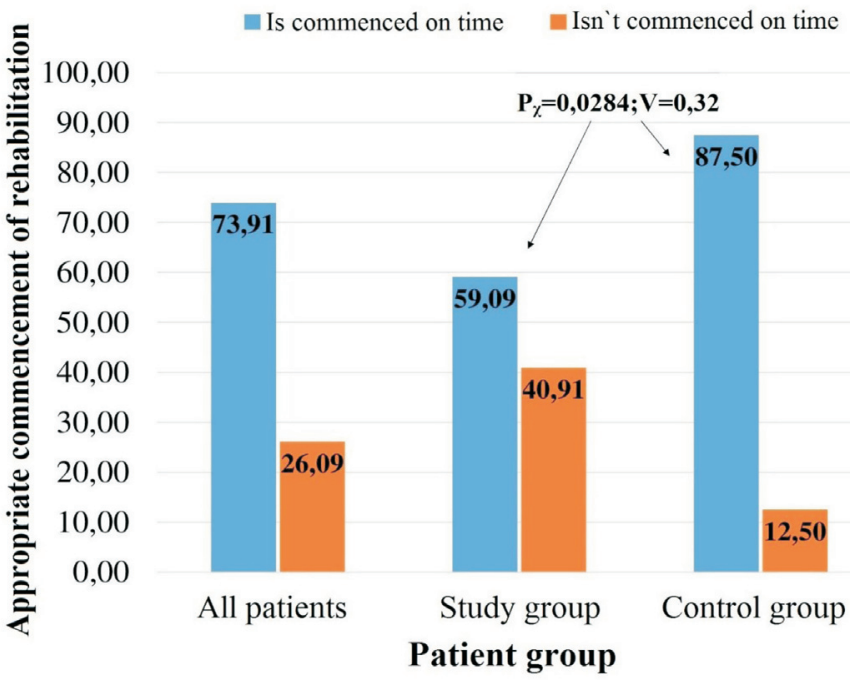

Fig. 1. Patient division distribution depending on the time when rehabilitation is commenced. $\mathrm{P}_{\chi}$, statistical significance using chi-squared test; $\mathrm{V}$, Cramer's V correlation coefficient.

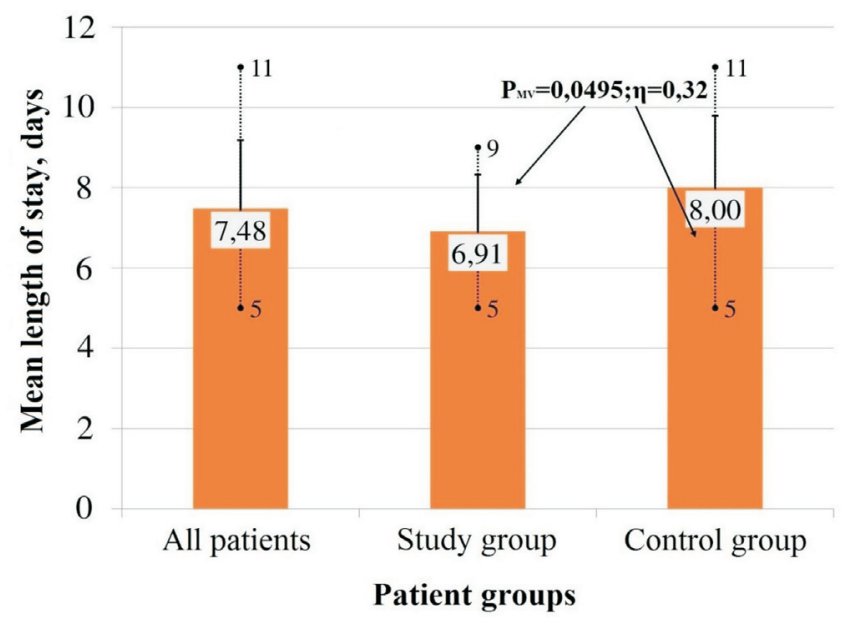

Fig. 2. Mean length of stay in hospital. Line represents mean with standard deviation; the dotted line is the limit between the smallest (min) and the largest (max) value; $P_{M V}$, statistical significance using Mann-Whitney test; $\eta$, Eta correlation coefficient.

showing that the relationship between duration of hospitalisation and the anaesthetic was weak $(\eta=0.32)$.

Regarding ability for self-care, $76.09 \%$ of all patients answered affirmatively, and $15.22 \%$ answered negatively (Fig. 3 ). In the study group, a positive response was given by $90.91 \%$, which was more than in the control group $62.50 \%$. Consequently, $25.00 \%$ of the control group were unable to ensure self-care. This difference was not statistically significant $\left(\mathrm{P}_{\chi}=0.07\right)$, but the correlation coefficient $(\mathrm{V}=0.32)$ suggested that significance would be obtained with a larger sample size.

\section{DISCUSSION}

The results showed that by combining this spinal anaesthetic with multimodal analgesia and early rehabilitation, postoperative pain was reduced during the first postopera-

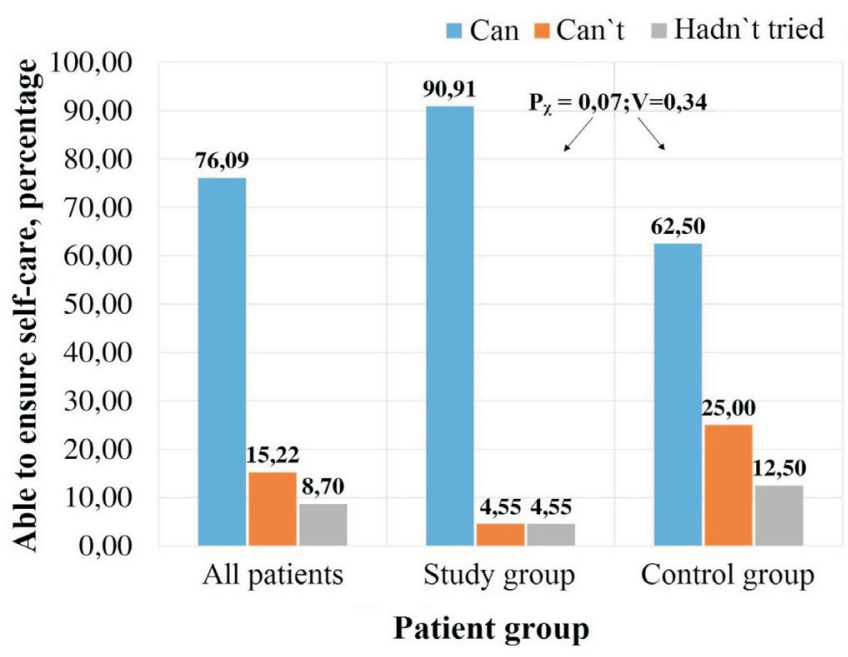

Fig. 3. Patient ability to ensure self-care. $\mathrm{P}_{\chi}$, statistical significance using chi-squared test; V, Cramer's V correlation coefficient.

tive day: NPRS 3.33 in the control group and 2.00 in the study group. The literature on prilocaine use involves only data from outpatient surgery, which makes it impossible to assess a patient's pain level during the first postoperative day. However, it should be emphasised that the surgeons involved in this study were able to perform the operations in a 90 -minute time window in $84.79 \%$ of the operation. The mean time for the operative part in both groups was 78.83 minutes, $\mathrm{SD}=12.59$ minutes (data from hospital archives). Similar studies using spinal anaesthesia were performed in 2006 in the United States, in 2009 in Denmark, and in 2013 in Sweden. The US study concluded that rehabilitation lessens pain when a patient is stationary, but does not statistically significantly affect pain during movement in the first postoperative day. However, this approach significantly reduced pain in the second postoperative day (Peters et al., 2006). A Danish study concluded that by using Fast-track protocols, patient pain levels were lower than in conventionally treated patients (Andersen et al., 2009). However, a Swedish study found that adding local anaesthetic infiltration to these protocols could reduce the risk of early postoperative pain during movement (Kuchalik et al., 2013). During the study, none of the patients in both groups had complications, which was in line with literature showing that the use of Fast-track protocols is safe and does not contribute to complications (Khan et al., 2014).

In the study, we found that use of a Fast-track protocol allowed shortening of the patient's stay in the hospital from 8 days to 6.91 days in comparison to the control group. Literature on outpatient surgery data after prilocaine use is available, but hip replacement is not included in these operations (Manaserro and Fannelli, 2018). However, several sources of literature show that the use of Fast-track protocols reduces the length of stay of patients. One recent study summarised information on 3000 patients in four Finnish hospitals and concluded that use of these protocols can reduce the length of stay from five to two days (Pamilo et al., 2018). Compared to Denmark, where fast-track protocols are used in very large number of hospitals, the average 
length of stay is 3.6 days (Anonymous, 2015). This has been particularly emphasized that the shortest length of stay was characteristic for hospitals where patients were mobilised on the day of surgery (Husted et al., 2009). However, it should be taken into account that the indicators from Finnish hospitals were better than the average in Latvia without the use of protocols. This can be explained by the fact that parts of these protocols, such as on patient education, limited use of drainage and urinary catheters have been introduced a long time ago (Pamilo et al., 2018).

It should be noted that in Latvia, in the framework of the state-paid hip replacement, patient stay in hospital for 10 days is already paid for, which reduces the patient's desire to go home sooner, because free rehabilitation outside of the hospital is not provided to these patients (Anonymous, 2018). In this study, it was found that using prilocaine, only $59.09 \%$ of patients managed to initiate rehabilitation at the scheduled time of surgery, compared to $87.50 \%$ of patients in the bupivacaine group it was. The literature mentions relatively little as to whether the planned mobilisation time corresponds to the implementation. However, a 2017 study in Australia indicated that only $9.4 \%$ of the cases were mobilised on the day of surgery, which was explained by various mobilisation protocols, different traditions, availability of staff and awareness of rehabilitation initiation, bladder catheters, the presence of acute complications and the need for blood transfusion (Chua et al., 2017). Our study also found that using prilocaine and early rehabilitation improved self-care capacity of patients, as $90.91 \%$ of patients are able to ensure self-care compared to $62.5 \%$ in the control group. Unfortunately, literature on patient self-care levels is available only starting from the third month after the discharge (Larsen et al., 2010), so it cannot be compared to our results.

This study is clinically relevant, as the results show that using short or intermediate-acting local anaesthetics in spinal anaesthesia and performing rehabilitation on the day of surgery reduces pain on the first day of the postoperative period and reduces the patient's residence time in the hospital, which improves the patient's well-being, quality of life and also lessens the risk of hospital acquired infections. It is possible that this method can also be used for other short or medium duration operations to improve the patient's condition and shorten the required length of stay. The study also had several drawbacks, such as small patient groups. In the course of the study, the author concluded that the majority of patients lacked information about the course of the operation, the expected post-operative period and the need for active participation in the recovery process. Also, the rehabilitation centre was not available at the hospital after 16:00 or on weekends, which limited the possibility of starting rehabilitation of patients. The literature on prilocaine use is only available from outpatient surgery, which extremely limits comparison of the patient pain levels, length of stay in the hospital and different aspects.
In general, the use of prilocaine in combination with local infiltration analgesia and same-day rehabilitation is a safe method, which can be used for patients at the Hospital of Traumatology and Orthopaedics to reduce postoperative pain during movement and the length of stay in the hospital, as well as to improve patient self-care abilities after discharge.

\section{REFERENCES}

Andersen, L. Ø., Gaarn-Larsen, L., Kristensen, B. B., Husted, H., Otte, K. S., Kehlet H. (2009). Subacute pain and function after fast-track hip and knee arthroplasty. Anaesthesia, 64, 508-513.

Anonymous (2015). Hospital discharges and length of stay statistics. Available from:http://ec.europa.eu/eurostat/statistics-explained/index.php?tile= Hospital_discharges_and_length_of_stay_statistics (accessed 10.08.2019).

Anonymous (2018). Regulation of the Cabinet of Ministers No. 1529. Available from: https://likumi.lv/doc.php?id=263457 .

Anonymous (2019). Numeric Pain Rating Scale. Available from: https://www.physio-pedia.com/Numeric_Pain_Rating_Scale (accessed 10.08.2019).

Bandholm, T., Kehlet, H. (2012). Physiotherapy exercise after Fast-Track total hip and knee arthroplasty: Time for reconsideration? Arch. Phys. Med. Rehab., 93 (7), 1292-1294

Chua, M. J., Hart, A. J., Mittal, R., Harris, I. A., Xuan, W., Naylor, J. M. (2017). Early mobilisation after total hip or knee arthroplasty: A multicentre prospective observational study. Isales, C. M. (Ed.). PLoS ONE, 12 (6), e0179820.

Husted H., Holm G., Jacobsen S. (2009). Predictors of length of stay and patient satisfaction after hip and knee replacement surgery: Fast-track experience in 712 patients. Acta Orthopaed., 79 (2), 168-173.

Kaban, O. G.,Yazicioglu, D, Akkaya, T., Sayin, M. M.,Seker, D., Gumus, H. (2014). Spinal anaesthesia with hyperbaric prilocaine in day-case perianal surgery: Randomised controlled trial. Sci. World J., 2014, Article ID 608372, 6 pp.

Kehlet, H. (1997). Multimodal approach to control postoperative pathophysiology and rehabilitation. Brit. J. Anaesth., 78 (5), 606-617.

Khan, S. K, Malviya, A., Muller, S. D,(2014). Reduced short-term complications and mortality following Enhanced Recovery primary hip and knee arthroplasty: Results from 6,000 consecutive procedures. Acta Orthopaed., 85 (1), 26-31.

Kuchálik, J., Granath, B., Ljunggren, A., Magnuson, A., Lundin, A., Gupta, A. (2013). Postoperative pain relief after total hip arthroplasty: A randomized, double-blind comparison between intrathecal morphine and local infiltration analgesia. Brit. J. Anaesth., 111 (5), 793-799.

Larsen, K., Hansen, T. B., Søballe, K., Kehlet, H. (2010). Patient-reported outcome after fast-track hip arthroplasty: A prospective cohort study. Health Qual. Life Outcomes, 8, 144.

Manassero, A., Fanelli, A. (2017). Prilocaine hydrochloride $2 \%$ hyperbaric solution for intrathecal injection: A clinical review. Local Reg. Anesth., 10, 15-24.

Okamoto, T., Ridley, R., Edmondston, S., Visser, M., Headford, J., Yates, P. (2015). Day-of-surgery mobilization reduces the length of stay after elective hip arthroplasty. J. Arthroplasty, 31 (10), 2227-2230.

Pamilo, K. J., Torkki, P., Peltola, M., Pesola, M., Remes, V., Paloneva, J. (2018). Reduced length of uninterrupted institutional stay after implementing a fast-track protocol for primary total hip replacement: Register-based analysis of 4 hospitals and 3,193 replacements. Acta Orthopaed., 89 (1), 10-16. 
Peters, C. L. (2006). The effect of a new multimodal perioperative anesthetic regimen on postoperative pain, side effects, rehabilitation, and length of hospital stay after total joint arthroplasty. J. Arthroplasty, 21 (6), 132-138.
Zagra, L. (2017). Advances in hip arthroplasty surgery: What is justified? EFORT Open Rev., 2 (5), 171-178.

Received 2 July 2018

Accepted in the final form 27 February 2019

FAST-TRACK KIRURGIJA UN AGRĪNA REHABILITĀCIJA PĒC TOTĀLAS GŪŽAS ENDOPROTEZĒ TRAUMATOLOĞIJAS UN ORTOPĒDIJAS SLIMNİCĀ

Sakarā ar populācijas novecošanu ir palielinājusies nepieciešamība pēc gūžas endoprotezēšanas operācijām, tādēl tiek meklēti jauni risinājumi, kā "Fast-track" princips, lai uzlabotu pacientu stāvokli, saīsinātu uzturēšanās ilgumu slimnīcā un uzlabotu slimnīcu spēju uzṇemt un ārstēt vairāk pacientu. Šì pētījuma mērkisis ir izpētīt agrīnas pacientu mobilizācijas ietekmi uz pēcoperācijas sāpēm, blaknēm, komplikācijām, uzturēšanās ilgumu un atveseḷošanos pēc gūžas locītavas endoprotezēšanas, lietojot vidēji ilgas darbības lokālos anestētiḳus spinālajā anestēzijā (SA). Prospektīvs, randomizēts pētījums tika veikts Traumatoloğijas un Ortopēdijas slimnīcā. Pētījumā tika iekḷauti 46 pacienti, kam bija paredzēta primāra totāla gūžas endoprotezēšana, viṇi tika iedalīti divās grupās. Pētījuma grupa (P) saņēma 70 mg tīra prilokaīna, bet kontroles grupa (B) sanēema $18 \mathrm{mg}$ smagā bupivakaīna. Pirmajā pēcoperācijas dienā pētījuma grupā sāpes kustību laikā bija 2,00 (P) un 3,33 (B) NPRS skalā. Uzturēšanās ilgums slimnīcā pētījuma grupai bija aptuveni par vienu dienu îsāks, un pacientu pašaprūpes spējas bija labākas pētījuma grupā. Lietojot "Fast-track" principu ar vidēji ilgas darbības spinālo anestēziju un agrīnu rehabilitāciju, ir iespējams samazināt pēcoperācijas sāpes kustību laikā, samazināt uzturēšanās ilgumu, kā arī uzlabot pacientu pašaprūpes spējas. 